\title{
The Effect of Unripe Dates (Phoenix dactylifera) on Rat Ovarian Follicle Maturation and Ovulation
}

\section{Efek Buah Kurma Muda (Phoenix dactylifera) terhadap Perkembangan Folikel Ovarium dan Ovulasi pada Tikus}

\author{
Herlambang $^{1}$, Ave Olivia Rahman ${ }^{2}$ Erny Kusdiyah ${ }^{3}$ \\ ${ }^{1}$ Department of Obstetrics and Gynecology Faculty of Medicine Universitas Jambi Jambi \\ ${ }^{2}$ Department of Pharmacology Faculty of Medicine Universitas Jambi Jambi \\ ${ }^{3}$ Department of Pubilc Health Faculty of Medicine Universitas Jambi Jambi
}

\begin{abstract}
Unripe dates are believed by Indonesian citizens to increase fertility. This study aimed to assess the effect of unripe dates in the ovary of rats. Fresh yellow-colored dates were dried in an oven and crushed into powder. Eighteen rats aged three months and had given birth once were randomly divided into three groups. The treatment groups were given unripe dates at doses of $160 \mathrm{mg} / \mathrm{kgBW}$ and $320 \mathrm{mg} / \mathrm{kgBW}$ through a feeding tube for 28 days, and the control group was only given distilled water. Histopathological examination was carried out by the pathology expert using Hematoxylin-Eosin staining to observe the number of ovarian follicles according to their maturation stage. The results showed that the administration

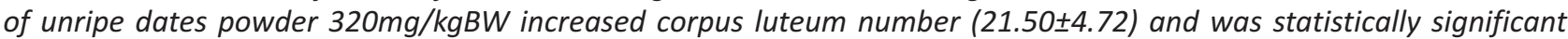
compared to the control group (15.16 \pm 3.71$)$. Similar differences were also found in other stages of the follicle although not statistically significant. Administration of unripe date powder can increase ovulation induction among fertile rats.
\end{abstract}

Keywords: Date palm fruit, follicle, histopathology, ovary, Phoenix dactylifera

\section{ABSTRAK}

Buah kurma muda dipercaya oleh masyarakat Indonesia dapat meningkatkan fertilitas. Penelitian ini bertujuan untuk menilai efek kurma muda terhadap organ ovarium tikus. Buah kurma muda yang berwarna kuning dikeringkan dalam oven dan dihaluskan menjadi serbuk. Delapan belas tikus berumur 3 bulan dan pernah melahirkan satu kali dibagi secara acak menjadi 3 kelompok. Kelompok perlakuan diberikan kurma muda dosis 160mg/kgBB dan 320mg/kgBB melalui sonde selama 28 hari dan kelompok kontrol hanya diberikan akuades. Pemeriksaan histopatologi dilakukan oleh ahli patalogi dengan pewarnaan Hematoksilin-Eosin untuk melihat jumlah folikel ovarium menurut tahap maturasinya. Hasil menunjukkan bahwa pemberian bubuk kurma muda dosis $320 \mathrm{mg} / \mathrm{kgBB}$ mempunyai jumlah korpus luteum lebih tinggi $(21,50 \pm 4,72)$ dan signifikan secara statistik bila dibandingkan kelompok kontrol $(15,16 \pm 3,71)$. Perbedaan serupa juga ditemukan pada folikel tahap lainnya meskipun secara statistik tidak signifikan. Pemberian bubuk kurma muda dapat meningkatkan induksi ovulasi pada tikus fertil.

Kata Kunci: Buah kurma, folikel ovarium, histopatologi, Phoenix dactylifera

Correspondence: Ave Olivia Rahman. Department of Pharmacology Faculty of Medicine Universitas Jambi, Jl. Letjen Soeprapto No. 33, Telanai pura, Kota Jambi.Telp081994616553Email:aveoliviarahman@unja.ac.id

DOI: http://dx.doi.org/10.21776/ub.jkb.2020.031.02.1 


\section{INTRODUCTION}

Infertility is defined as the inability to obtain pregnancy after one year of regular intercourse without contraception (1). The prevalence of infertility in 2010 globally is $1.9 \%$ for primary infertility and $10.5 \%$ secondary infertility. Infertility prevalence is highest in South Asia, Sub Saharan African, North Africa/Middle East, Central/East Europe, and Central Asia (2). Infertility prevalence in Indonesia is about 15-20\% in 2009 (3).

Infertility may arise from male factors, female factors, or both. Female infertility factors contribute to approximately $50 \%$ of all infertility cases caused by ovulation disorders, uterine abnormalities, tubal obstruction, and peritoneal factors (1). Anovulation accounts for $25-50 \%$ of the causes of female infertility (4). Infertility can cause a psychological problem, such as anxiety and depression (5). About $80 \%$ of couples tried out traditional medicine for their infertility since it is available, cheap, and has a variety of health benefits $(6,7)$.

Many herbal medicines are believed to have a positive effect on the reproductive organs, hormonal system, and sex drive (8-10). Based on our survey, unripe date is one of herbal medicine that is believed can increase the fertility in infertile women. They usually consume about five yellow colored-dates each day or equally with about 9 grams in dried weight. Another study has identified the content of estrone, estradiol, and estriol in date palm powder(11).

Scientific data about the effect of unripe dates to increase fertility in women is still limited. This study aimed to assess the effect of unripe date in the ovary of rats by histopathological assessment. Rats were used in this study because the maturation and ovulation of rats are similar to humans (12).

\section{METHODS}

This study was approved by the ethics committee of the Faculty of Medicine and Health Sciences, University of Jambi, with number 632/UN21.6/LT/2018.

\section{Date Preparation}

Fresh yellow-colored dates were bought from a local market. Dates fruit were cut and dried in an oven at $70^{\circ} \mathrm{C}$. The dried dates were crushed by using a blender to obtain a powder form which was then stored in a dark container during the experiment.

\section{Animal Preparation}

The animals used in this study were female Sprague Dawley strain rats, fertile (had given birth once), weighed between 130-200 gram, and aged 3-4 months. Rats were given food ad libitum in the form of pellets and water and kept individually at stable room temperature.

\section{Research Design}

A total of 18 rats were randomly divided into three groups. The dose $160 \mathrm{mg} / \mathrm{kgBW}$ that used in this study was the conversion of date's dried weight that usually consumed by women based on our previous survey. Group I was treated with a date powder dose of $160 \mathrm{mg} / \mathrm{kgBW}$, group II was treated with date powder dose of $320 \mathrm{mg} / \mathrm{kgBW}$, and group III as the control group was given distilled water.
Dates were weighed according to individual doses and dissolved using distilled water to reach $2 \mathrm{~mL}$ in volume. The administration of dates was done by using a feeding pipe once per day for 28 days that started when the rats were in the estrous phase. An estrous phase is a phase in the estrous cycle of mice or rats when ovulation happens (13). The determination of the estrous phase was held according to the previous study (14). After the treatment was completed, on day 29 , each rat in every group was terminated, ovaries were taken and immediately fixed on $10 \%$ neutral buffered formalin as a histological assessment specimen.

\section{Histological Assessment}

The ovaries were separated and fixed in $10 \%$ neutral buffered formalin and then dehydrated in an ascending grade of ethanol, cleaned using xylene, and embedded in paraffin. Slide cutting was done with a thickness of 5 microns using a rotatory microtome. Slides were stained with hematoxylin and eosin (HE) staining. Slides were read by the anatomic pathologist using a blind method. The ovarian assessment was done by counting each type of follicle in both rat ovaries.

\section{Statistical Analysis}

Ovarian assessment results were displayed in mean \pm SD, and data were tested using the Kruskal-Wallis test followed by the Mann-Whitney test. The $p$-value $<0.05$ indicated a significant result.

\section{RESULTS}

The number of the various stage of ovary follicles is shown in Table 1. The number of corpus luteum in the treatment groups was higher than the control group. Corpus luteum number in group treated with unripe dates dose of $320 \mathrm{mg} / \mathrm{kgBW}$ was significantly higher than that of the control groups $(21.50 \pm 4.72$ vs $15.16 \pm 3.71)$. There was a dose-dependent pattern, a higher dose of dates had a higher number of corpus luteum. The number of corpus luteum in the group treated with a dose of $320 \mathrm{mg} / \mathrm{kgBW}$ was higher than the group treated with a dose of $160 \mathrm{mg} / \mathrm{kgBW}(21.50 \pm 4.72$ vs $17.83 \pm 9.33)$. The number of secondary and tertiary follicles in the group treated with an unripe date at a dose of $320 \mathrm{mg} / \mathrm{kgBW}$ was also higher than control group, although not statistically significant.

Table 1. Mean of follicle's number in each group

\begin{tabular}{lrrr}
\hline \multirow{2}{*}{ Variable } & Control & \multicolumn{2}{l}{ Treatment } \\
\cline { 3 - 4 } & & $\begin{array}{l}\text { Dose of 160 } \\
\mathrm{mg} / \mathrm{kgBW}\end{array}$ & $\begin{array}{l}\text { Dose of 320 } \\
\mathrm{mg} / \mathrm{kgBW}\end{array}$ \\
\hline Secondary follicle & $6.16 \pm 2.63$ & $8.33 \pm 4.12$ & $9.83 \pm 5.77$ \\
Tertiary follicle & $2.00 \pm 0.89$ & $2.00 \pm 1.41$ & $3.00 \pm 2.75$ \\
De Graaf's follicle & $0.16 \pm 0.41$ & 0.00 & 0.00 \\
Corpus luteum & $15.16 \pm 3.71$ & $17.83 \pm 9.33$ & $21.50 \pm 4.72 *$ \\
\hline
\end{tabular}

*Mann-Whitney test when compared with the control group $(p<0.05)$

The results of the ovarian histopathological examination are presented in Figure 1. Figure 1 shows the variation of follicular maturation in the groups treated with dates. The figure also presents different characteristics of follicular types according to their levels of maturity. 


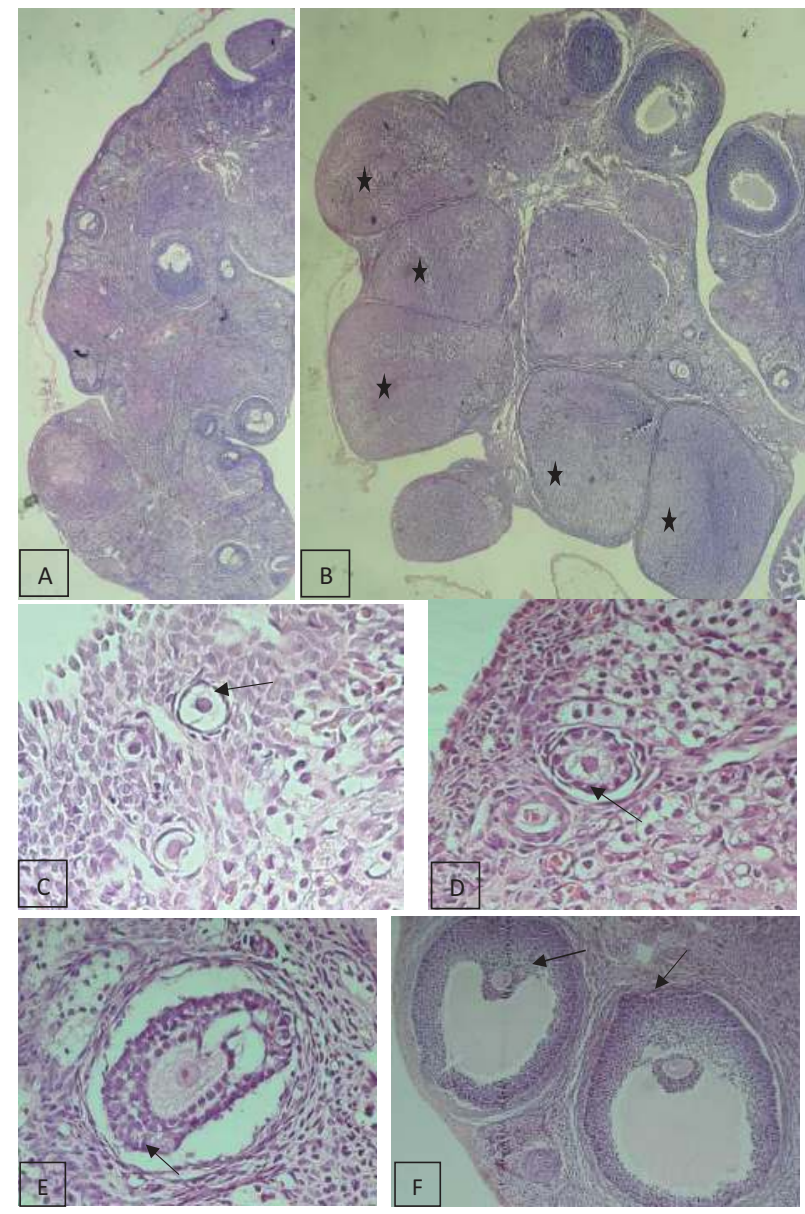

Figure 1. Histopathological image of rats' ovaries of the groups given dates powder

Note:

A. Cortex, consisting of many follicles with various stages of maturation (10x magnification).

B. Multiple corpus luteum, star symbols (B, 10x magnification).

C. Primordial follicles, consisting of oocytes surrounded by squamous follicles (40x magnification)

D. Primary follicles, consisting of oocytes surrounded by a layer of columnar cells (40x magnification).

E. Secondary follicles, consisting of oocytes surrounded by a zone of granulosa cells layer (40x magnification).

F. Tertiary follicles, having a large central cavity, follicular antrum surrounded by granulosa zones. The oocyte is in an eccentric position and is surrounded by granulosa cells called corona radiate. Theca cells from tertiary follicles are divided into two zones; internal puzzles and external puzzles (40x magnification)

\section{DISCUSSION}

Growth and maturation of an ovarian follicle (folliculogenesis) begin with primordial follicle into secondary, tertiary, de Graaf follicle and ends with ovulation. De Graaf follicle will become a corpus luteum after ovulation so that the corpus luteum is a product of

\section{REFERENCES}

1. Lindsay TJ and Vitrikas KR. Evaluation and Treatment of Infertility. American Family Physician. 2015; 91(5): 308-314.

2. Mascarenhas MN, Flaxman SR, Boerma T, Vanderpoel S, and Stevens GA. National, Regional, and Global Trends in Infertility Prevalence since ovulation. Growth and maturation of ovary follicle and ovulation in rodents and humans are similar. The difference is that multiple follicles could mature and occur ovulation simultaneously in the ovary of rodents (12).

This study showed that the treatment groups had a higher number of secondary and tertiary follicles than the control group. Also, the number of corpus luteum in the treatment groups were higher than the control group. Dates powder at a dose of $320 \mathrm{mg} / \mathrm{kgBW}$ induced a significant increase in the number of corpus luteum than the control group. Dates powder at a dose of $160 \mathrm{mg} / \mathrm{kgBW}$ increased the number of corpus luteum but not significant when compared to the control group. The effect of dates was likely dose-dependent. The numbers of de Graaf follicles in the treatment groups were fewer compared to the control group. Dates likely had an effect on follicular maturation and ovulation induction, so that all de Graaf follicles have ovulated and turned into the corpus luteum. This study confirms the results of another study on palm date. Date pollen has been proven to increase the weight of the gonads and sex accessory organs, follicular development, and sexual hormone $(15,16)$.

Ovulation is a process that is controlled by luteinizing hormone (LH) and follicle-stimulating hormone (FSH). FSH and $\mathrm{LH}$ bind to each receptor on multiple follicles and stimulate these cells to transduce signals that collectively lead to follicle growth and maturation, and also ovulation. The expressions of FSH and LH's receptors on multiple follicle cells determine the amount of signal transduction for follicular growth and maturation and ovulation. The stimulus to FSH and LH's receptors appears to facilitate the expression of genes important for ovulation, such as Cyclooxygenase- 2 (COX-2) gene expression. The COX-2 enzyme is responsible for increasing prostaglandin levels. Prostaglandin is one of the key mediators for ovulation $(17,18)$. Other mediator factors also regulate the development of ovary follicle and ovulation, such as steroid hormones, cytokines, and growth factors $(18,19)$.

The mechanism of ovulation induction by dates could likely be through stimulation of ovulatory mediators, such as COX-2 enzyme or other ovulatory mediators. Dates have many compounds such as several amino acids, vitamins, estrone, estradiol, and estriol, also flavonoids and quercetin. These compounds may be responsible for the effect of dates on the induction of ovulation (11).

We conclude that unripe dates affect the induction of ovarian follicles maturation and ovulation in the rat. Further research is needed to determine the definite mechanism of dates in inducing ovarian follicle maturation and ovulation.

\section{ACKNOWLEDGMENT}

Medical and Health Science Faculty, Universitas Jambi for funding the research.

1990: A Systematic Analysis of 277 Health Surveys. PLoS Medicine. 2012; 9(12): 1-12.

3. Direktorat Jenderal Pelayanan Kesehatan Kementerian Kesehatan Republik Indonesia. Infertilitas. (Online). http://www.yankes. kemkes. go.id/read--infertilitas-7828.html

4. Weiss RV and Clapauch R. Female Infertility of 
Endocrine Origin. Arquivos Brasileiros de Endocrinologia \& Metabologia. 2014; 58(2): 144-152.

5. Rooney KL and Domar AD. The Relationship between Stress and Infertility. Dialogues in Clinical Neuroscience. 2018; 20 (1): 41-47.

6. Jaradat $\mathrm{N}$ and Zaid AN. Herbal Remedies Used for the Treatment of Infertility in Males and Females by Traditional Healers in the Rural Areas of the West Bank/Palestine. BMC Complementary and Alternative Medicine. 2019; 19: 1-12.

7. Bennett $L R$, Wiweko B, Hinting A, Adnyana IBP, and Pangestu M. Indonesian Infertility Patients' Health Seeking Behaviour and Patterns of Access to Biomedical Infertility Care: An Interviewer Administered Survey Conducted in Three Clinics. Reproductive Health. 2012; 9(24): 1-7.

8. Lans C, Taylor-Swanson L and Westfall R. Herbal Fertility Treatments Used in North America from Colonial Times To 1900, and Their Potential for Improving the Success Rate of Assisted Reproductive Technology. Reproductive BioMedicine and Society Online. 2018; 5: 60-81.

9. Teng B, Peng J, Ong $M$ and Qu X. Successful Pregnancy after Treatment with Chinese Herbal Medicine in a 43-Year-Old Woman with Diminished Ovarian Reserve and Multiple Uterus. Medicines. 2017; 4(7): 1-5.

10. Kashani $L$ and Akhondzadeh S. Female Infertility and Herbal Medicine. Journal of Medicinal Plants. 2017; 16(61): 16-20.

11. Tahvilzadeh M, Hajimahmoodi M, and Rahimi R. The Role of Date Palm (Phoenix dactylifera L) Pollen in Fertility: A Comprehensive Review of Current Evidence. Journal of Evidence-Based Complementary \& Alternatives Medicine. 2016; 21(4): 320-324.
12. Boyd KL, Muehlenbachs A, Rendi MH, Garcia RL and Gibson-Corley KN. Female Reproductive System. In: Treuting PM, Dintzis SM, and Montine KS (Eds). Comparative Anatomy and Histology a Mouse, Rat, and Human Atlas 2nd edition. Washington: Elsivier; 2018; p. 303-310.

13. Sato J, Nasu M, and Tsuchitani M. Comparative Histopathology of the Estrous or Menstrual Cycle in Laboratory Animals. Journal of Toxicologic Pathology. 2016; 29(3): 155-162.

14. Caligioni C. Assessing Reproductive Status/Stages in Mice. Current Protocol in Neuroscinece. 2009; 48(1): A.41.1-A.41.8.

15. Hosseini E, Mehrabani D, and Razavi F. Effect of Palm Pollen Extract on Sexual Hormone Levels and Follicle Numbers in Adult Female BALB/C mice. Quarterly of the Horizon of Medical Sciences. 2014; 20(3): 139143.

16. Jihell MJ and Arrak JK. Effect of Different Doses of Ethanolic Extract of Date Palm Pollen Grains on Serum Gonadotropin and Total Glutathione in Mature Female Rats. Kufa Journal for Veterinary Medical Sciences. 2015; 6(2): 109-116.

17. Edelman AB, Jensen JT, Doom C, and Hennebold JD. Impact of the Prostaglandin-Synthase 2 Inhibitor Celecoxib on Ovulation and Luteal Events in Women. Contraception. 2013; 87(3): 352-357.

18. Williams CJ and Erickson GF. Morphology and Physiology of the Ovary. Endotext [Internet]. (Online) 2000. https://www.ncbi.nIm.nih.gov/ books/NBK278951/\#top

19. Takagi K, Yamada T, Miki Y, Umegaki T, Nishimura M, and Sasaki J. Histological Observation of the Development of Follicles and Follicular Atresia in Immature Rat Ovaries. Acta Medica Okayama. 2007; 61(5): 283-298. 